\title{
PENGARUH PENGGUNAAN GEL LIDAH BUAYA (Aloe Vera) PADA PEMBUATAN SABUN CAIR DENGAN PEWANGI MINYAK NILAM (Patchouli Oil)
}

\author{
Endo Pebri Dani Putra ${ }^{1}$, Sahadi Didi Ismanto ${ }^{2}$, Diana Silvy ${ }^{2}$ \\ ${ }^{1}$ Teknologi Industri Pertanian, Institut Teknologi Sumatera, Lampung Selatan \\ ${ }^{2}$ Teknologi Hasil Pertanian, Universitas Andalas, Sumatera Barat \\ E-mail: endo.putra@tin.itera.ac.id
}

\begin{abstract}
This research was aimed to determine the effect of aloe vera gel to liquid soap moisturize activities of liquid soapto skin, and to determine the best addition of aloe vera gel. This research used a completely randomized design (CRD) consisting of 5 treatments and 3 replications. Data were analyzed statistically using ANOVA followed by Duncan test's New Multiple Range Test (DNMRT) at $5 \%$ level. Treatment in the present research is the addition of aloe vera gel at $0 \% ; 6 \% ; 7 \% ; 8 \%$; and $9 \%$. Observations on the resulting liquid soap products were organoleptic, physical properties, chemical properties of soap, antimicrobial test, moisturize activities test, and irritation test. The physical propertiestest to soaps include viscosity, specific gravity and total foam. For chemical propertiestest to soaps include $\mathrm{pH}$ andfree alkali. The results showed that the difference in concentration of aloe vera gel to liquid soap significantly affected to viscosity, $\mathrm{pH}$, antimicrobial and moisture activities of product and did not significantly affected to specific gravity, free alkali, and total foam. The best products based on organoleptic test on liquid soap was treatment B (addition of aloe vera gel $6 \%$ ).
\end{abstract}

Keyword: aloe vera gel; liquid soap

\section{PENDAHULUAN}

Infeksi kulit masih menjadi suatu masalah kesehatan yang dihadapi masyarakat di negara berkembang termasuk Indonesia. kasus penyakit kulit dan jaringan subkutan lainnya menempati urutan ketiga pada kasus penyakit terbanyak pasien rawat jalan di Rumah Sakit tahun 2010 yaitu sebanyak 247.179 kasus dengan kasus baru sebesar 60,77\% Kementerian Kesehatan RI (2011). Hal tersebut memicu kebutuhan akan perlindungan non-alamiah yaitu perlindungan dengan menggunakan kosmetika pelembab seperti sabun.

Sabun merupakan pembersih yang dibuat dengan reaksi kimia antara kalium atau natrium dengan asam lemak dari minyak nabati atau lemak hewani, Qisti (2009). Sabun dapat berwujud padat atau cair. Sabun cair lebih diminati oleh masyarakat dibandingkan dengan sabun padat, karena penggunaannya yang lebih praktis, lebih hemat, tidak terkontaminasi bakteri, mudah dibawa dan mudah disimpan, Apgar (2010).

Semakin berkembangnya teknologi dan penggunaan sabun pada saat ini, bahan-bahan yang digunakan dalam pembuatan sabun pun semakin bervariasi. Penambahan bahan alami yang aman bagi kesehatan pada sabun cair perlu dikembangkan. Hal ini dimaksudkan untuk memberikan pengaruh positif atau fungsi tertentu terhadap sabun cair yang dihasilkan. Fungsi tersebut antara lain memberikan kesan halus, kesan lembut, melembabkan kulit dan memiliki aktivitas antibakteri dan dapat mengharumkan badan bila digunakan. Selain itu, dengan penambahan bahan alami tersebut diharapkan dapat memperbaiki tekstur dan penampakan serta kandungan kimia sabun cair. (Gandasasmita, 2009). Salah satu produk hasil pertanian yang memiliki fungsi tersebut yaitu gel daun lidah buaya dan minyak nilam.

Menurut penelitian sebelumnya lidah buaya banyak dimanfaatkan dalam perawatan kesehatan dan kecantikan serta pengobatan. Pemakaiannya untuk menyuburkan rambut, perawatan kulit, obat luka dan antimikroba (Setiabudi, W.A. 2008). Senyawa atau komponen-komponen dalam lidah buaya seperti lignin mampu menembus dan meresap ke dalam kulit agar terjaga kelembabannya, saponin mempunyai aktifitas antiseptik dan pembersih, dan antrakuinon yang berguna sebagai bahan dasar obat yang mempunyai sifat sebagai antibiotik, antibakterial, antifungi, dan penghilang rasa sakit.

Selain menggunakan gel lidah buaya, dalam pembuatan sabun cair ini juga menggunakan minyak nilam sebagai pewangi. Minyak nilam mempunyai komponen utama patchouli alkohol. 
Minyak nilam banyak sekali dipakai sebagai bahan baku dalam industri parfum. Selain itu minyak nilam juga bersifat fiksatif dan sifat fiksatif inilah tidak dapat digantikan oleh minyak apapun. Penggunaan minyak atsiri sebagai aromaterapi pada sabun adalah berkisar antara 1-7\% (Muchtaridi, 2008), sehingga peneliti menggunakan konsentrasi 5\% dalam penambahan minyak nilam.

Penelitian Soebagio, Sriwidodo dan Irni mengenai formulasi sabun mandi cair dengan lendir daun lidah buaya (Aloe vera) berbagai konsentrasi. Hasil penelitian ini menunjukkan bahwa sabun mandi cair dengan lendir daun lidah buaya dengan konsentrasi 3,6 dan 9\% aman untuk digunakan. Sabun mandi cair dengan konsentrasi $6 \%$ dan 9\% mempunyai aktivitas untuk melembabkan dan menghaluskan kulit yang kering. Berdasarkan hasil penelitian tersebut konsentrasi $6 \%$ dan $9 \%$ merupakan formula yang terbaik, maka berdasarkan hasil ini penulis akan mengambil konsentrasi yang terbaik dan mengoptimasinya. Konsentrasi terbaik yang dioptimasi adalah antara 6-9\%, sehingga konsentrasi penambahan gel lidah buaya dimulai dari $0 \%, 6 \%, 7 \%, 8 \%$ dan $9 \%$.

Berdasarkan uraian diatas, maka dilakukan penelitian dengan tujuan mengetahui pengaruh penambahan gel lidah buaya (Aloe vera) terhadap karakteristik sabun cair serta mengetahui konsentrasi gel lidah buaya (Aloe vera) yang terbaik untuk menghasilkan kualitas sabun cair yang baik dan daya melembabkan kulit.

\section{METODOLOGI PENELITIAN}

\section{A. Bahan dan alat}

Bahan yang digunakan dalam penelitian ini adalah minyak kelapa, $\mathrm{KOH}$, aquades, gel daun lidah buaya (Aloe vera), minyak nilam (Patchouli oil), CMC, gliserin dan methyl paraben sebagai pengawet. Bahan yang digunakan dalam analisis kimia berupa aquades, alkohol, aseton, larutan buffer $\mathrm{HCl} 0,1 \mathrm{~N}$, Indikator PP.

Alat-alat yang digunakan selama penelitian adalah gelas ukur, termometer, magnetic stirrer, hot plate. cawan alumunium, gelas ukur, erlenmeyer, oven, gelas piala, pipet $1 \mathrm{ml}, \mathrm{pH}$ meter, viskotester, desikator, microtube, jangka sorong, seperangkat penangas air dan cawan petri.

\section{B. Rancangan Penelitian}

Rancangan yang digunakan dalam penelitian ini adalah Rancangan Acak Lengkap (RAL) dengan 5 perlakuan dan 3 kali ulangan. Data pengamatan dianalisis dengan uji $\mathrm{F}$ dan jika berbeda nyata dilanjutkan dengan uji Duncan's New Multiple Range Test (DNMRT) pada taraf 5\%. Perlakuan yang digunakan adalah penambahan gel lidah buaya. Kelima perlakuan tersebut adalah:

$\mathrm{A}=$ Tanpa penambahan gel daun lidah buaya.

$\mathrm{B}=$ Penambahan $6 \%$ gel daun lidah buaya.

$\mathrm{C}=$ Penambahan $7 \%$ gel daun lidah buaya.

$\mathrm{D}=$ Penambahan $8 \%$ gel daun lidah buaya.

$\mathrm{E}=$ Penambahan $9 \%$ gel daun lidah buaya.

\section{Pelaksanaan Penelitian}

\section{Pembuatan Gel Lidah Buaya (Modifikasi TKTM, 2013)}

Gunting salah satu lonjor lidah buaya yang gemuk/berisi, potong sedekat mungkin dari badannya. Potong bagian berduri sepanjang lonjor lidah buaya Belah memanjang pada penampang yang lebar menggunakan pisau hingga menjadi dua bagian. Letakkan bagian yang berisi gel menghadap ke atas dan keruk gel dari atas ke bawah, dari ujung ke bagian pangkal lidah buaya. Blender dan masukkan dalam botol.

\section{Pembuatan Sabun Cair}

Masukkan minyak kelapa sebanyak 30 g kedalam erlenmeyer $250 \mathrm{ml}$, dipanaskan pada suhu $70^{\circ} \mathrm{C}$ selama 5 menit. Ditambahkan dengan kalium hidroksida sebanyak 3.6 g, kemudian diaduk hingga mendapatkan sabun pasta. Sabun pasta ditambahkan dengan $20 \mathrm{~g}$ aquades, lalu dimasukkan natrium karboksi metil selulosa $1 \mathrm{~g}$, diaduk hingga homogen. Kemudian ditambahkan gliserin $1 \mathrm{~g}$, diaduk hingga homogen. Dimasukkan gel daun lidah buaya, diaduk hingga homogen. Pengadukan dengan magnetic stirrer $350 \mathrm{rpm}$ sampai homgogen suhu dipertahankan sekitar $70-80^{\circ} \mathrm{C}$. Selanjutnya turunkan suhu menjadi $40^{\circ} \mathrm{C}$, tambahkan minyak nilam sebanyak $5 \%$, diaduk hingga homogen. 
Kemudian masukkan methyl paraben sebanyak $0,1 \%$ dan diaduk hingga homogen. Sabun cair kemudian masukkan ke dalam wadah bersih yang telah disiapkan.

\section{Pengamatan}

Pengamatan yang dilakukan yaitu terhadap gel lidah buaya dan sabun cair dengan gel lidah buaya. Pengamatan terhadap gel lidah buaya adalah uji fisik yaitu uji $\mathrm{pH}$, kadar air, viskositas dan bobot jenis. Pengamatan pada sabun cair adalah karakteristik sabun cair yang dibedakan atas uji organoleptik, sifat fisik, sifat kimia sabun, uji antimikroba dan uji kelembaban produk dan uji iritasi.

\section{HASIL DAN PEMBAHASAN}

\section{A. Uji Kualitas Gel Lidah Buaya}

Gel lidah buaya merupakan komponen yang akan dilihat pengaruhnya terhadap sabun cair. Pengujian gel perlu dilakukan untuk mengetahui kualitas dari gel yang akan digunakan. Hasil pengamatan terhadap kualitas gel lidah buaya dapat dilihat pada Tabel 1.

Tabel 1. Hasil Pengamatan terhadap Kualitas Gel Lidah Buaya

\begin{tabular}{ccc}
\hline No. & Pengamatan & Hasil \\
\hline 1 & $\mathrm{pH}$ & 4.8 \\
2 & Kadar air & $99.47 \%$ \\
3 & Viskositas & $293 \mathrm{Cp}$ \\
4 & Bobot jenis & $1.01 \mathrm{~g} / \mathrm{ml}$ \\
\hline
\end{tabular}

Pada Tabel 1 dapat dilihat hasil pengamatan pada gel lidah buaya (Aloe vera) yang digunakan memiliki $\mathrm{pH}$ sebesar 4.8, sedangkan pada literatur $\mathrm{pH}$ gel lidah buaya adalah sebesar 4.3 (Ariyani dan Hidayati, 2018). Nilai pH gel lidah buaya yang digunakan dalam penelitian ini mendekati dengan nilai pH dalam penelitian Ariyani dan Hidayati, (2018).

Menurut Hartawan (2012) kandungan air pada lidah buaya mempunyai kadar air yang cukup tinggi, yaitu 95,510\%. Pada pengamatan yang telah dilakukan gel lidah buaya yang digunakan memiliki kadar air $99.47 \%$ sehingga dapat dikatakan bahwa kadar air gel lidah buaya yang digunakan dalam penelitian sudah memenuhi persyaratan.

Viskositas gel lidah buaya yang digunakan dalam penelitian ini adalah sebesar 293 cP, sedangkan dalam literatur gel lidah buaya memiliki viskositas sebesar $275 \mathrm{cP}$. Gel lidah buaya yang digunakan dalam penelitian ini memiliki bobot jenis $1.01 \mathrm{~g} / \mathrm{ml}$, sedangkan dalam literatur bobot jenis gel lidah buaya adalah $0,996 \mathrm{~g} / \mathrm{ml}$.

\section{B. Uji Organoleptik}

Uji organoleptik merupakan salah satu uji penerimaan yang menyangkut penerimaan seseorang terhadap kesukaan terhadap suatu produk. Uji organoleptik dapat menentukan tingkat kesukaan panelis terhadap sabun cair. Hasil pengamatan organoletik terhadap warna, aroma, kekentalan dan banyak busa dapat dilihat pada Tabel 2 .

Tabel 2. Hasil Organoleptik Sabun Cair terhadap Warna, Aroma, dan Kekentalan.

\begin{tabular}{lrccc}
\hline Perlakuan & \multicolumn{4}{c}{ Parameter suka + sangat suka (\%) } \\
\hline & Warna & Aroma & Kekentalan & Banyak busa \\
\hline A (Tanpa penambahan gel lidah buaya) & 83 & 57 & 50 & 57 \\
B (Penambahan gel lidah buaya 6\%) & 83 & 47 & 70 & 67 \\
C (Penambahan gel lidah buaya 7\%) & 50 & 40 & 63 & 60 \\
D (Penambahan gel lidah buaya 8\%) & 30 & 47 & 67 & 47 \\
E (Penambahan gel lidah buaya 9\%) & 60 & 47 & 60 & 60 \\
\hline
\end{tabular}

Pada Tabel 2 dapat dilihat bahwa hasil organoleptik sabun cair dengan penambahan gel lidah buaya terhadap warna berkisar antara 30\% - 83\%. Perlakuan yang paling disukai adalah perlakuan A dan B (Tanpa Penambahan Gel Lidah Buaya dan Penambahan Gel Lidah Buaya 6\%) yaitu 83\%, 
sedangkan yang paling sedikit disukai adalah perlakuan D (Penambahan Gel Lidah Buaya 8\%), yaitu $30 \%$. Penambahan gel lidah buaya mempengaruhi warna sabun cair yang dihasilkan. Ini disebabkan karena gel lidah buaya adanya hidrolisis polisakarida oleh enzim yang masih mempunyai aktivitas tinggi dan diikuti oleh perubahan warna menjadi gelap. Gel lidah buaya memiliki sifat sangat mudah teroksidasi karena mengandung enzim oksidase. Akibatnya, kontak bahan dengan udara akan mempercepat proses oksidasi, sehingga gel akan berubah menjadi kuning hingga coklat (Wardhanu, 2009).

Hasil organoleptik sabun cair terhadap aroma diperoleh dari rata-rata pada tahap suka dan sangat suka berkisar antara 40-57\%. Dari kelima perlakuan yang banyak disukai adalah perlakuan A (Tanpa Penambahan Gel Lidah Buaya) dengan persentase panelis yang menyukai sebesar 57\% sedangkan perlakuan yang sedikit disukai adalah pada perlakuan C (Penambahan Gel Lidah Buaya $7 \%$ ) yaitu dengan persentase panelis yang menyukai sebesar $40 \%$. Penambahan gel lidah buaya pada sabun cair tidak mempengaruhi aroma sabun cair yang dihasilkan. Pada setiap sabun cair memiliki aroma yang sama, yaitu aroma minyak nilam. Kandungan utamanya minyak nilam adalah patchouly alkohol yang berkisar antara $30-50 \%$ dan merupakan senyawa yang menentukan bau minyak nilam. Minyak nilam memiliki potensi strategis di pasar dunia sebagai bahan pengikat dan juga menghasilkan aroma wangi pada parfum dan kosmetika. Minyak nilam dapat berfungsi sebagai zat pengikat (fiksatif) dan tidak dapat digantikan dengan zat sintetis lainnya. Minyak nilam sebagai aromatik merupakan minyak eksotik yang dapat meningkatkan gairah dan semangat serta mampunyai sifat meningkatkan sensualitas. Minyak nilam dapat memberikan efek menenangkan dan membuat tidur lebih nyenyak sehingga minyak nilam dapat digunakan untuk aroma terapi karena mempunyai efek sedatif.

Hasil organoleptik sabun cair terhadap kekentalan diperoleh rata-rata pada tahap suka dan sangat suka berkisar antara 50-70\%. Dari kelima perlakuan yang paling disukai adalah perlakuan B (Penambahan Gel Lidah Buaya 6\%), yaitu dengan persentase 70\%. Sedangkan perlakuan yang paling sedikit disukai adalah pada perlakuan A (Tanpa Penambahan Gel Lidah Buaya), yaitu dengan persentase $50 \%$. Penambahan gel lidah buaya pada sabun cair mempengaruhi kekentalan sabun cair yang dihasilkan. Semakian tinggi penambahan konsentrasi gel lidah buaya maka kekentalan sabun cair yang dihasilkan semakin rendah.

Hasil organoleptik terhadap kadar busa berkisar antara 47-67\%. Pada uji organoleptik, perlakuan yang banyak disukai adalah perlakuan B (Penambahan Gel Lidah Buaya 6\%) yaitu 70\% sedangkan perlakuan yang paling sedikit disukai adalah perlakuan D (Penambahan Gel Lidah Buaya $8 \%$ ), yaitu $47 \%$. Penambahan gel lidah buaya pada sabun cair tidak mempengaruhi banyak busa sabun cair yang dihasilkan.

\section{Analisis Fisik Sabun Cair}

\section{Viskositas}

Viskositas merupakan salah satu parameter penting yang menunjukkan stabilitas produk maupun untuk penanganan suatu produk kosmetik dan toiletries selama distribusi produk (Nurhadi, 2012). Hasil pengamatan viskositas dapat dilihat pada Tabel 3.

Tabel 3. Viskositas Sabun Cair dengan Penambahan Gel Lidah Buaya

\begin{tabular}{ll}
\hline \multicolumn{1}{c}{ Perlakuan } & Viskositas (cP)* \\
\hline E (Penambahan gel lidah buaya 9\%) & $3.533 \mathrm{~b}$ \\
B (Penambahan gel lidah buaya 6\%) & $3.700 \mathrm{~b}$ \\
C (Penambahan gel lidah buaya 7\%) & $3.833 \mathrm{~b}$ \\
D (Penambahan gel lidah buaya 8\%) & $3.833 \mathrm{~b}$ \\
A (Tanpa penambahan gel lidah buaya) & $4.367 \quad$ a \\
\hline KK $=0,12 \%$ & \\
\hline
\end{tabular}

*Angka-angka yang diikuti oleh huruf yang tidak sama menunjukkan nilai berbeda nyata menurut DNMRT pada taraf nyata $5 \%$.

Pada Tabel 3 dapat dilihat bahwa viskositas sabun cair bervariasi dan ada kecenderungan menurun akibat perbedaan konsentrasi gel lidah buaya yang ditambahkan. Viskositas tertinggi yaitu pada sabun cair tanpa penambahan gel lidah buaya sebesar $4.367 \mathrm{cP}$ dan viskositas terendah pada 
sabun cair dengan konsentrasi gel lidah buaya 9\% sebesar $3.533 \mathrm{cP}$. Viskositas sabun cair ikut berpengaruh terhadap penerimaan konsumen terhadap sabun cair. Selain itu, nilai viskositas yang tinggi akan mengurangi frekuensi tumbukan antar partikel di dalam sabun sehingga sediaan lebih stabil (Gandasasmita, 2009).

Penelitian Nurhadi (2012), menyatakan bahwa viskositas suatu produk bergantung pada viskositas pelarut, kontribusi bahan terlarut dan integrasi dari keduanya. Dalam penelitian ini, pelarut yang digunakan dalam formulasi sabun cair yang dihasilkan adalah aquades. Karena aquades memiliki viskositas yang sangat rendah, maka aquades tidak berpengaruh secara siginifikan terhadap viskositas sabun mandi cair, kecuali jika ditambahkan dalam jumlah besar akan menurunkan viskositas dari produk. Sedangkan untuk kontribusi bahan terlarut terdapat penambahan agen pengental, yaitu karboksi metil selulosa (CMC) sebesar $1 \mathrm{~g}$ sedangkan bahan terlarut lainnya adalah gel lidah buaya. Karena gel lidah buaya yang ditambahkan sebagian besar kandungannya adalah air. Sehingga dapat menurunkan viskositas sabun cair dan juga dapat dikatakan bahwa nilai viskositas sabun cair yang dihasilkan sangat bergantung pada variabel penambahan bahan terlarutnya.

\section{Bobot Jenis}

Bobot jenis menurut SNI 06-4085-1996 didefinisikan sebagai perbandingan bobot sabun cair dengan bobot air pada volume dan suhu yang sama. Bobot jenis sabun cair yang telah ditetapkan dalam Standar Nasional Indonesia (SNI 06-4085-1996) yaitu sebesar 1,01-1,10 g/ml. Hasil pengamatan bobot jenis dapat dilihat pada Tabel 4 .

Tabel 4. Bobot Jenis Sabun Cair dengan Penambahan Gel Lidah Buaya

\begin{tabular}{|c|c|}
\hline Perlakuan & Bobot Jenis, $2^{\circ} \mathrm{C}(\mathrm{g} / \mathrm{ml})$ \\
\hline A (Tanpa penambahan gel lidah buaya) & 1.09 \\
\hline B (Penambahan gel lidah buaya 6\%) & 1.20 \\
\hline C (Penambahan gel lidah buaya 7\%) & 1.21 \\
\hline D (Penambahan gel lidah buaya 8\%) & 1.22 \\
\hline E (Penambahan gel lidah buaya 9\%) & 1.23 \\
\hline $\mathrm{KK}=0,04 \%$ & \\
\hline
\end{tabular}

Pada Tabel 4 dapat bahwa bobot jenis sabun cair cenderung meningkat akibat perbedaan konsentrasi gel lidah buaya yang ditambahkan. Dapat dilihat pula bahwa bobot jenis tertinggi yaitu pada sabun cair dengan konsentrasi gel lidah buaya $9 \%$ sebesar $1,23 \mathrm{~g} / \mathrm{ml}$ dan bobot jenis terendah pada sabun cair tanpa penambahan gel lidah buaya sebesar $1,09 \mathrm{~g} / \mathrm{ml}$.

Jika suatu bahan dilarutkan dalam air dan membentuk larutan maka densitasnya akan mengalami perubahan. Perubahan nilai bobot jenis diduga dipengaruhi jenis dan konsentrasi bahan dalam larutan. Kebanyakan bahan-bahan seperti gula dan garam menyebabkan peningkatan densitas, tetapi kadang-kadang densitas dapat turun jika terdapat lemak dan etanol. Karena dalam gel lidah buaya mengandung senyawa-senyawa gula dalam bentuk mannose, glukosa, serta sejumlah kecil silosa, arabinosa, galaktosa, ramnosa dan enzim-enzim oksidase (Tim Karya Tani Mandiri, 2013).

\section{Banyak Busa}

Busa adalah dispersi gas dalam cairan yang distabilkan oleh suatu zat pembusa, merupakan struktur yang relatif stabil dan terdiri atas kantong-kantong udara yang terbungkus oleh lapisan tipis (Ayu, et al., 2010). Pada penggunaanya, busa berperan dalam proses pembersihan dan melimpahkan wangi sabun pada kulit. Uji tinggi busa dilakukan untuk melihat banyaknya busa dihasilkan oleh sabun mandi cair. Hasil pengamatan banyak busa dapat dilihat pada Tabel 5.

Pada Tabel 5 dapat dilihat bahwa rata-rata banyak busa sabun transparan secara kuantitatif berkisar antara 63.7-67.2\%. Sedangkan hasil organoleptik terhadap kadar busa berkisar antara 47$67 \%$. Pada uji organoleptik, perlakuan yang banyak disukai adalah perlakuan B (Penambahan Gel Lidah Buaya $6 \%$ ) yaitu $70 \%$ sedangkan perlakuan yang paling sedikit disukai adalah perlakuan D (Penambahan Gel Lidah Buaya 8\%), yaitu 47\%. 
Tabel 5. Banyak Busa Sabun Cair dengan Penambahan Gel Lidah Buaya.

\begin{tabular}{lc}
\hline \multicolumn{1}{c}{ Perlakuan } & Kadar Busa Kuantitatif (\%) \\
\hline D (Penambahan gel lidah buaya 8\%) & 63.7 \\
B (Penambahan gel lidah buaya 6\%) & 63.9 \\
A (Tanpa penambahan) & 64.7 \\
C (Penambahan gel lidah buaya 7\%) & 67.2 \\
E (Penambahan gel lidah buaya 9\%) & 67.2 \\
\hline KK $=1,07 \%$ &
\end{tabular}

Karakteristik busa sendiri dipengaruhi oleh adanya bahan aktif sabun atau surfaktan, penstabil busa, serta komposisi asam lemak yang digunakan. Asam laurat dan miristat dapat menghasilkan busa yang lembut, sementara asam palmitat dan stearat memiliki sifat menstabilkan busa. Asam oleat dan risinoleat dapat menghasilkan busa yang stabil dan lembut Widiyanti, (2009).

\section{Analisis Kimia Sabun Cair}

1. $\mathrm{pH}$

Derajat keasaman $(\mathrm{pH})$ dapat mempengaruhi daya absorpsi kulit. Derajat keasaman atau $\mathrm{pH}$ merupakan parameter kimiawi untuk mengetahuai sabun yang dihasilkan bersifat basa atau asam (Widiyanti, 2009). Hasil pengamatan pH dapat dilihat pada Tabel 6.

Tabel 6. Nilai pH Sabun Cair dengan Penambahan Gel Lidah Buaya

\begin{tabular}{ll}
\hline \multicolumn{1}{c}{ Perlakuan } & \multicolumn{1}{c}{$\mathbf{p H}^{*}$} \\
\hline B (Penambahan gel lidah buaya 6\%) & $10.18 \mathrm{a}$ \\
A (Tanpa penambahan gel lidah buaya) & $10.21 \mathrm{a}$ \\
C (Penambahan gel lidah buaya 7\%) & $10.46 \quad \mathrm{~b}$ \\
D (Penambahan gel lidah buaya 8\%) & $10.48 \quad \mathrm{~b}$ \\
E (Penambahan gel lidah buaya 9\%) & $10.68 \quad \mathrm{~b}$ \\
\hline KK $=0,03 \%$ & \\
\hline
\end{tabular}

*Angka-angka yang diikuti oleh huruf yang tidak sama menunjukkan nilai berbeda nyata menurut DNMRT pada taraf nyata $5 \%$.

Dari Tabel 6 dapat dilihat bahwa nilai $\mathrm{pH}$ rata-rata sabun cair yang dihasilkan berkisar antara 10,18 - 10,68. Nilai $\mathrm{pH}$ semua perlakuan pada sabun cair ini telah memenuhi standar yang ditetapkan SNI 06-4085-1996, yaitu berkisar 8-11. Hasil pengujian terhadap pH sabun cair menunjukkan bahwa produk sabun cair memiliki $\mathrm{pH}$ basa hal ini karena bahan dasar penyusun sabun cair adalah $\mathrm{KOH}$ yang bersifat basa kuat. Hasil pengamatan $\mathrm{pH}$ sabun cair menunjukkan bahwa semakin tinggi konsentrasi penambahan gel lidah buaya maka semakin tinggi $\mathrm{pH}$ sabun cair yang dihasilkan. Sesuai dengan hasil penelitian yang dilakukan oleh Gusviputri, dkk. (2013), bahwa semakin banyak lendir lidah buaya yang ditambahkan maka sabun mandi akan semakin basa yang mengakibatkan $\mathrm{pH}$ sabun mandi juga semakin tinggi.

\section{Alkali Bebas}

Alkali bebas yang ada dalam sabun merupakan alkali (dalam hal ini $\mathrm{KOH}$ ) yang tidak habis bereaksi dengan asam lemak pada saat pembentukan pasta sabun. Adanya alkali dalam bentuk bebas menandakan kurangnya jumlah asam lemak dalam formula sabun. Hasil pengamatan alkali bebas dapat dilihat pada Tabel 7.

Tabel 7. Kadar Alkali Bebas Sabun Cair

\begin{tabular}{lc}
\hline Perlakuan & Kadar Alkali Bebas (\%) \\
\hline C (Penambahan gel lidah buaya 7\%) & 0.001 \\
A (Tanpa penambahan gel lidah buaya) & 0.001 \\
D (Penambahan gel lidah buaya 8\%) & 0.001 \\
B (Penambahan gel lidah buaya 6\%) & 0.002 \\
E (Penambahan gel lidah buaya 9\%) & 0.003 \\
\hline KK $=0,06 \%$ & \\
\hline
\end{tabular}


Dari Tabel 7 dapat dilihat bahwa rata-rata kadar alkali bebas sabun cair yang dihasilkan berkisar antara $0,001-0,003 \%$. Kadar alkali bebas sabun cair yang dihasilkan telah memenuhi SNI 06-4085-1996, yaitu maksimal 0,1\% sehingga dapat dikatakan bahwa sabun cair ini aman untuk digunakan. Bila dibandingkan dengan penelitian Gandasasmita (2009) yaitu pemanfaatan kitosan dan karagenan pada produk sabun cair kadar alkali bebas produk sabun cair yang dihasilkan juga rendah yaitu sebesar $0,017 \%$. Hal ini menunjukkan bahwa dalam pembuatan sabun minyak tersabunkan dengan baik. Suatu sabun cair yang baik kualitasnya kadar alkali bebas yang masih tersisa tidak boleh melebihi 0,22 \% yang dihitung sebagai KOH (WHO Collaborating Centre for Quality Assurance of Essential Drugs 1990). Karena kelebihan kadar alkali dari batasan resmi tersebut dapat menimbulkan kerugian konsumen, berupa kerusakan kulit seperti iritasi kulit.

\section{E. Aktivitas Antimikroba}

Analisis ini dilakukan untuk mengetahui diameter hambat sabun cair dengan penambahan gel lidah buaya terhadap pertumbuhan bakteri Staphylococcus aureus. Hasil pengamatan diameter hambat dapat dilihat pada Tabel 8 .

\begin{tabular}{lc}
\multicolumn{2}{c}{ Tabel 8. Diameter Hambat Bebas Sabun Cair } \\
\hline Perlakuan & Diameter $(\mathrm{mm})^{*}$ \\
\hline A (Tanpa penambahan gel lidah buaya) & $15.0 \mathrm{a}$ \\
B (Penambahan gel lidah buaya 6\%) & $17.7 \mathrm{a}$ \\
D (Penambahan gel lidah buaya 8\%) & $18.3 \mathrm{a}$ \\
C (Penambahan gel lidah buaya 7\%) & $22.4 \mathrm{~b}$ \\
E (Penambahan gel lidah buaya 9\%) & $24.1 \mathrm{~b}$ \\
\hline KK $=0,18 \%$ & \\
\hline
\end{tabular}

*Angka-angka yang diikuti oleh huruf yang tidak sama menunjukkan nilai berbeda nyata menurut DNMRT pada taraf nyata $5 \%$.

Dari Tabel 8 dapat dilihat bahwa nilai diameter antimikroba rata-rata sabun cair yang dihasilkan berkisar antara 15,0-24,1 $\mathrm{mm}$. Respon daya hambat sabun cair gel lidah buaya terhadap uji mikroba berdasarkan kategori daya hambat menurut Greenwood (1995) adalah sebagai berikut: Diameter zona hambat $\leq 10 \mathrm{~mm}$ dikatakan tidak menghambat pertumbuhan mikroba uji $(\mathrm{T})$, diameter 11-15 mm dikategorikan lemah (L), diameter 16-20 mm dikategorikan sedang (S) dan diameter $>20$ mm dikategorikan kuat $(\mathrm{K})$. Berdasarkan klasifikasi diatas bahwa sabun cair tanpa penambahan gel lidah buaya yang mempunyai daya hambat yang lemah dan sabun cair dengan penambahan gel lidah buaya daya hambatnya sedang dan kuat.

Diameter hambat bakteri Staphylococcus aureus tertinggi terlihat pada perlakuan E (Penambahan gel lidah buaya 9\%) yaitu $24,1 \mathrm{~mm}$ dan diameter hambat bakteri Staphylococcus aureus terendah terlihat pada perlakuan A (Tanpa penambahan gel lidah buaya) yaitu 15,0 $\mathrm{mm}$.

Dari hasil analisa dapat dilihat bahwa semakin tinggi konsentrasi gel lidah buaya yang ditambahkan pada sabun cair, maka diameter hambat pertumbuhan bakteri Staphylococcus aureus juga semakin besar. Hal ini disebabkan karena kandungan saponin, kompleks anthraguinone dan acemannan yang terdapat dalam gel lidah buaya (Tim Karya Tani Mandiri, 2013). Dan juga dikarenakan gel lidah buaya mengandung berbagai macam zat seperti kompleks antraquinon, yang memiliki efek sebagai senyawa antibakteri dan saponin yang mempunyai kandungan antibiotik (Putri dan Tiana, 2017).

\section{F. Uji Kelembaban Produk (Water Holding Capacity)}

Pengujian kelembaban produk dilakukan untuk mengetahui kestabilan produk terhadap kehilangan air karena penguapan (water holding capacity). Kelembaban produk sabun cair dinyatakan sebagai kemampuan produk sabun cair dalam mempertahankan beratnya terhadap pengaruh sinar matahari. Hasil pengamatan kelembaban produk dapat dilihat pada Tabel 9.

Pada Tabel 9 dapat dilihat bahwa kelembaban produk sabun cair ada kecenderungan menurun akibat perbedaan konsentrasi gel lidah buaya yang ditambahkan. Pada Tabel juga dapat dilihat bahwa nilai kelembaban produk rata-rata sabun cair yang dihasilkan berkisar antara 99,06 - 99,53\%. Kelemababan produk tertinggi terlihat pada perlakuan C (Penambahan gel lidah buaya 7\%) yaitu 
99,53\% dan kelemababan produk terendah terlihat pada perlakuan D (Penambahan gel lidah buaya $8 \%$ ) yaitu 99,06\%.

Tabel 9. Uji kelembaban produk Bebas Sabun Cair dengan Penambahan Gel Lidah Buaya

\begin{tabular}{ll}
\hline \multicolumn{1}{c}{ Perlakuan } & \multicolumn{1}{c}{ Kelembaban Produk (\%)* } \\
\hline D (Penambahan gel lidah buaya 8\%) & $99.06 \mathrm{a}$ \\
E (Penambahan gel lidah buaya 9\%) & $99.14 \mathrm{a}$ \\
A (Tanpa penambahan gel lidah buaya) & $99.26 \mathrm{~b}$ \\
B (Penambahan gel lidah buaya 6\%) & $99.30 \mathrm{~b}$ \\
C (Penambahan gel lidah buaya 7\%) & $99.53 \quad \mathrm{c}$ \\
\hline KK = 0\% & \\
\hline da-angka yang diikuti oleh huruf yang tidak sama menunjukkan nilai berbeda nyata menurut DNMRT
\end{tabular}

Dari hasil yang didapatkan bahwa dengan semakin tinggi penambahan gel lidah buaya pada sabun cair maka kemampuan produk dalam mempertahankan kelembabannya tidak semakin turun. Hasil ini menunjukkan bahwa penambahan gel lidah buaya dapat meningkatakan dan menurunkan kemampuan produk dalam mempertahankan kelembabannya.

Viskositas juga merupakan faktor yang dapat mempengaruhi kelembaban produk. Produk dengan viskositas yang tinggi merupakan indikasi ikatan yang kuat diantara molekul-molekul penyusunnya. Dengan demikian, produk yang memiliki viskositas yang tinggi cendrung lebih dapat mempertahankan campuran dari kehilangan berat (Hidayat, 2006). Dalam penelitian ini viskositas sabun cair cendrung turun yaitu dari $4.367-3.533 \mathrm{cP}$, sehingga dengan turunnya viskositas maka kemampuan produk dalam mempertahankan kelembabannya juga rendah atau turun yaitu dari 99,53 $99,06 \%$.

\section{G. Uji Iritasi}

Uji iritasi salah satu parameter yang sangat pentig karena melihat efek yang ditimbulkan pada kulit setelah menggunakan sabun cair dengan penambahan gel lidah buaya. Hasil pengamatan uji iritasi dapat dilihat pada Tabel 10.

\begin{tabular}{lc} 
Tabel 10. Nilai Iritasi Bebas Sabun Cair dengan Penambahan Gel Lidah Buaya \\
\hline \multicolumn{1}{c}{ Perlakuan } & Nilai Iritasi \\
\hline A (Tanpa penambahan gel lidah buaya) & 0 \\
B (Penambahan gel lidah buaya 6\%) & 0 \\
C (Penambahan gel lidah buaya 7\%) & 0 \\
D (Penambahan gel lidah buaya 8\%) & 0 \\
E (Penambahan gel lidah buaya 9\%) & 0 \\
KK =0\% & \\
Keterangan: 0 = Tidak menimbulkan iritasi
\end{tabular}

Dari Tabel 10 menunjukkan bahwa penggunaan sabun cair dengan penambahan gel lidah buaya tidak menimbulkan iritasi pada kulit. Iritasi kulit disebabkan oleh $\mathrm{pH}$ yang terlalu tinggi atau terlalu rendah, serta jumlah alkali bebas yang tinggi. $\mathrm{pH}$ bukanlah parameter utama yang menyebabkan kulit menjadi teriritasi. Parameter utama penyebab iritasi kulit pada sabun adalah alkali bebas. Kadar alkali bebas yang tinggi (di atas $0,22 \%$ ) dapat menyebabkan iritasi pada kulit dan biasanya kadar alkali bebas yang tinggi ditandai pula dengan $\mathrm{pH}$ sabun yang terlalu basa ( $\mathrm{pH}$ diatas 11) (Wdyasanti, dkk. 2017). Dalam penelitian ini, $\mathrm{pH}$ dan alkali bebas pada sabun telah memenuhi standar mutu menurut SNI 06-3532-1994, Sehingga sabun cair ini aman untuk digunakan.

\section{KESIMPULAN}

Penambahan gel lidah buaya pada pembuatan sabun cair memberikan pengaruh nyata terhadap karakteristik sabun cair yang dihasilkan. Produk terbaik berdasarkan uji organoleptik sabun cair adalah perlakuan B (Penambahan gel lidah buaya 6\%), dengan rata-rata panelis yang menyatakan suka dan sangat suka terhadap warna $83 \%$, aroma $47 \%$, kekentalan $70 \%$, dan banyak busa $67 \%$. 


\section{DAFTAR PUSTAKA}

Ariyani dan Hidayati. 2018. Penambahan gel lidah buaya sebagai antibakteri pada sabun mandi cair berbahan dasar minyak kelapa. Jurnal industri hasil perkebunan. Vol 13. No. 1 Juni 2018: 1118.

Apgar, Satrias. 2010. Formulasi Sabun Mandi Cair yang Mengandung Gel Daun Lidah Buaya (Aloe vera (L) Webb) dengan Basis Virgin Coconut Oil (VCO). Skripsi. Fakultas Matematika dan Ilmu Pengetahuan Alam Universitas Islam Bandung: Bandung.

Ayu, Dewi Fortuna., Akhyar Ali dan Rudianda Sulaiman. 2010. Evaluasi Mutu Sabun Padat dari Minyak Goreng Bekas Makanan Jajanan di Kecamatan Tampan Kota Pekan Baru dengan Penamabahan Natrium Hidroksida dan Lama Waktu Penyabunan. Prosiding SEMNAS 2010. Riau: Fakultas Pertanian Universitas Riau.

Gandasasmita, hangga DP. 2009. Pemanfaatan Kitosan dan Karagenan pada Produk Sabun Cair. [Skripsi]. Bogor. Institute Pertanian Bogor.

Gusviputri, A., Njoo Meliana P. S., Aylianawati, Indraswati, Nani. 2013. Pembuatan sabun dengan lidah buaya (aloe vera) sebagai antiseptik alami. Widya Teknik Vol. 12, No. 1, 11-21.

Hidayat, F. 2006. Pengaruh Kombinasi Karagenan Dan Sodium Lauryl Sulfat Serta Penambahan Ekstrak Pemphis Acidula Terhadap Karakteristik Sabun Mandi Cair [skripsi]. Bogor: Program Studi Teknologi Hasil Perikanan, Fakultas Perikanan Dan Ilmu Kelautan, Institut Pertanian Bogor.

Hartawan.E.Y. 2012. Sejuta khasiat lidah buaya. Pustaka Diantara. Perpustakaan Nasional.

Muchtaridi. 2018. Pengembangan minyak atsiri sebagai aromaterapi dan potensinya sebagai produk sediaan farmasi. Padjajaran. Unpad.

Nurhadi, Siely C. 2012. Pembuatan sabun mandi gel alami dengan Bahan aktif mikroalga chlorella pyrenoidosa Beyerinck dan minyak atsiri Lavandula latifolia chaix.

Setiabudi, W.A. 2008. Lidah buaya. Teknologi Hasil Pertanian. Universitas Brawijaya.

[SNI] Standar nasional Indonesia. 06-4085-1996. Standar Mutu Sabun Mandi Cair. Jakarta: Dewan Standar Nasional.

[TKTM] Tim Karya Tani Mandiri. 2013. Pedoman Bertanam Lidah Buaya. Nuansa Aulia: Bandung. 14-24 hal.

Qisti, R. 2019. Sifat kimia sabun trasnparan dengan penambahan madu pada konsentrasi yang berbeda. Bogor. IPB.

Wardhanu, A. P., 2009. Rekayasa sistem penyimpanan dengan teknologi control atmosphere dan modified atmosphere storage untuk memperpanjang umur simpan buah. http://www.apwardhanu.wordpress.com [31 Maret 2010].

WHO Collaborating Centre for Quality Assurance of the Essential Drugs. 1990. Penetapan Kadar Alkali Bebas Jumlah pada Sabun Mandi. Dalam: Metode Analisis Pusat Pemeriksaan Obat dan Makanan. Jakarta: Depkes RI. 143-148.

Widiyanti, Yunita. 2009. Kajian pengaruh jenis minyak terhadap mutu sabun transparan. Skripsi. Teknologi Agroindustri. Institut Pertanian Bogor. Bogor. 